\title{
Prevalence and Characterization of Typical Aeromonas salmonicida Chum Salmon Isolates in Korea
}

\author{
Yong-Seok Kim ${ }^{1, a}$, Jang Won Yoon ${ }^{2}$, Hyun-Ja Han ${ }^{3, b}$, Rungkarn Suebsing ${ }^{1}$ and Jeong-Ho Kim ${ }^{1 *}$ \\ ${ }^{1}$ Department of Marine Bioscience and Technology, Gangneung-Wonju National University, Gangneung 210-702, Korea \\ ${ }^{2}$ Department of Food Science and Engineering, Ewha Womans University, Seoul 120-750, Korea \\ ${ }^{3}$ ECO Marine Bio Center, Chonnam National University, Yeosu 550-749, Korea \\ ${ }^{a}$ Present address: Gangwondo Freshwater Resources Research Institute, Chuncheon 200-853, Korea \\ ${ }^{\mathrm{b}}$ Present address: Aquatic Life Disease Control Division, Fundamental Research Department, National Fisheries Research and \\ Development Institute, Busan 619-705 Korea
}

\begin{abstract}
Aeromonas salmonicida is an important fish pathogen commonly associated with furunculosis in salmonids. Typical A. salmonicida strains have the surface virulence A-layer protein, a major virulence determinant encoded by the vapA gene. In this study, 880 chum salmon Oncorhynchus keta were collected from the east coast of Korea during 2006-2011, including 560 wild adults and 320 artificially hatched fry pools, and the presence of typical $A$. salmonicida was examined by PCR using the typical $A$. salmonicida-specific vapA gene primers. The results demonstrated that $34.5 \%$ of the samples (304/880 samples) were PCR positive, implying that a typical A. salmonicida infection is highly prevalent among chum salmon in Korea. Twenty typical A. salmonicida isolates were recovered based on their brown pigmentation on Trypticase Soy Agar (TSA) plates, which indicates the existence of the A-layer protein. Further biochemical analyses with the four randomly selected typical $A$. salmonicida isolates revealed some variations in their amino acid decarboxylation and carbohydrate fermentation activity. A phylogenetic analysis based on the entire vapA gene sequence suggested that the A. salmonicida isolates from chum salmon were clustered with those isolated from Atlantic salmon in Europe. Further study is needed to resolve such an interesting relationship in detail.
\end{abstract}

Key words: typical Aeromonas salmonicida, Oncorhynchus keta, furunculosis, chum salmon, vapA gene

\section{Introduction}

Aeromonas salmonicida is an important fish pathogen that has a geographically widespread distribution, with a broad host range and an economically destructive impact on cultivated fish, particularly salmonids (Trust et al., 1980; Fryer et al., 1988; Johnsen and Jensen, 1994; Mooney et al., 1995; Nomura et al., 2002). As a member of the family Aeromonadaceae, A. salmonicida has been classified into typical and atypical A. salmonicida pathogroups (Wiklund and Dalsgaard, 1998; Abbott et al., 2003). The "typical" group of $A$. salmonicida is frequently associated with furunculosis in salmonids. Such a group strain includes $A$. salmonicida subsp. salmonicida. In contrast, the "atypical" group of $A$. salmonicida is involved in various ulcerative diseases or atypical furunculosis in salmonids and non-salmonids (Wiklund and Dalsgaard, 1998). Other A. salmonicida subspecies such as A. salmonicida subsp. achromogenes, masoucida, smithia, and pectinolytica belong in this atypical A. salmonicida group (Wiklund and Dalsgaard, 1998). Although a classification has been created according to both genetic and biochemical characteristics of individual A. salmonicida strains, subspecies populations unable to be
Open Access http://dx.doi.org/10.5657/FAS.2011.0347

This is an Open Access article distributed under the terms of the Creative Commons Attribution Non-Commercial License (http://creativecommons. org/licenses/by-nc/3.0/) which permits unrestricted non-commercial use, distribution, and reproduction in any medium, provided the original work is properly cited. pISSN: 2234-1749 eISSN: 2234-1757
Received 1 July 2011; Revised 16 September 2011; Accepted 7 November 2011

*Corresponding Author

E-mail: jhkim70@gwnu.ac.kr 
classified under these criteria have been increasing; thus, more reliable classification methods are needed for atypical $A$. salmonicida strains (Lund et al., 2003).

Previous studies have reported that both typical and atypical $A$. salmonicida infections occur worldwide, including in North America, Europe, and Japan (Trust et al., 1980; Fryer et al., 1988; Mooney et al., 1995; Nomura et al., 2002). Among the various $A$. salmonicida fish host species, salmonids are the most susceptible to furunculosis (Lund and Mikkelsen, 2004; Austin and Austin, 2007). In Korea, A. salmonicida subsp. salmonicida was isolated from cultured masu salmon (Oncorhynchus masou) in 1986 (Fryer et al., 1988) and more recently detected by the PCR from rearing water on a trout farm (Lee et al., 2002). However, A. salmonicida subsp. salmonicida has not been reported in other salmonids in Korea until now. In this study, the prevalence of typical $A$. salmonicida was examined in both migrating wild chum salmon and artificially hatched fry during 2006-2011 in Korea by PCR using typical A. salmonicida-specific vapA gene primers. Because the vapA gene encodes the surface virulence A-layer protein, the vap $A$ positive and A-layer-expressing typical $A$. salmonicida were isolated and further characterized using both biochemical and phylogenetic analyses.

\section{Materials and Methods}

\section{Sample collection}

Wild adults and artificially hatched chum salmon fry samples were randomly collected from the Namdae River basin and hatcheries at Yangyang City (located on the east coast of South Korea) during 2006-2011. The number of chum salmon samples in this study is listed in Table 1. Both kidney and spleen from individual wild adult chum salmon were collected after artificial spawning and used for the PCR analysis. Artificially hatched fry samples were randomly selected and euthanized with excess MS-222 (tricaine methane sulfonate; Sigma; St. Louis, MO, USA). Five individual fry were pooled and considered as 1 fry sample for the PCR analysis. Subsequent bacterial isolation was conducted for all PCR-positive adult samples as described below.

\section{Isolation and identification of $A$. salmonicida}

One hundred mg of adult chum salmon kidney were aseptically sampled and homogenized with $900 \mu \mathrm{L}$ of phosphatebuffered saline. Each homogenate $(100 \mu \mathrm{L})$ was spread directly on trypticase soy agar (TSA; Difco, Detroit, MI, USA) and furunculosis agar (FA) plates containing 1\% tryptone (Difco), $0.5 \%$ yeast extract (Oxoid, Hampshire, UK), 0.1\% L-tyrosine (Sigma), and $0.25 \%$ sodium chloride. If brown-pigmented colonies appeared on the plates after a $15^{\circ} \mathrm{C}$ incubation for 2-7 days, they were selected and sub-cultured in trypticase soy broth (Difco) for a preliminary biochemical screening, including Gram staining and assessment of oxidase activity and catalase production, as previously described (Austin and Austin, 2007). Further biochemical characterization of the $A$. salmonicida isolates was performed using the API 20E kit (BioMerieux, Marcy l'Etoile, France) according to the manufacturer's instructions. Bacterial growth on Coomassie Brilliant Blue agar (CBBA) plates was examined as previously described (Cipriano and Bertolini, 1988) to confirm the presence of the surface A-layer.

\section{Antimicrobial susceptibility}

Antimicrobial susceptibilities were tested using a standard disk diffusion assay and Mueller-Hinton agar plates (Difco). The diameters of bacterial growth inhibitory zones were measured and interpreted according to NCCLS guidelines (National Committee for Clinical Laboratory Standard, 2001).

\section{Genomic DNA preparation}

Genomic DNA was extracted from $100 \mathrm{mg}$ of salmon tissue sample or $5 \mathrm{~mL}$ of cultured bacterial cells using the AccuPrep Genomic DNA Extraction kit (Bioneer, Seoul, Korea) accord-

Table 1. Prevalence of the typical A. salmonicida infection among the chum salmon populations in Korea during 2006 and 2011

\begin{tabular}{|c|c|c|c|c|c|c|c|c|}
\hline Type of sample & PCR analysis & 2006 & 2007 & 2008 & 2009 & 2010 & 2011 & Total \\
\hline \multirow[t]{3}{*}{ Adults } & No. of the samples & 60 & 140 & 120 & 120 & 120 & ND & 560 \\
\hline & A. salmonicida-positive & 28 & 61 & 51 & 25 & 15 & - & 180 \\
\hline & A. salmonicida-positive (\%) & 46.7 & 43.6 & 42.5 & 20.8 & 12.5 & - & 32.1 \\
\hline \multirow[t]{3}{*}{ Fry pools ${ }^{*}$} & No. of the samples & ND & 40 & 70 & 49 & 66 & 95 & 320 \\
\hline & A. salmonicida-positive & - & 38 & 70 & 14 & 2 & 0 & 124 \\
\hline & A. salmonicida-positive (\%) & - & 95.0 & 100.0 & 28.6 & 3.0 & 0.0 & 38.8 \\
\hline
\end{tabular}

ND, no data.

* One pool contains 5 random fries. 
ing to the manufacturer's instructions. All genomic DNA was adjusted to a final concentration of $100 \mathrm{ng} / \mu \mathrm{L}$ for the PCR analysis.

\section{PCR detection of typical $A$. salmonicida using the vapA gene-specific primers}

The PCR amplification was performed to detect a partial vapA gene specific to typical $A$. salmonicida using the primers AP1 (5'-GGC TGA TCT CTT CAT CCT CAC CC-3') and AP2 (5'-CAG AGT GAA ATC TAC CAG CGG TGC-3'), as previously described (Gustafson et al., 1992). The target gene was amplified with $25 \mu \mathrm{M}$ of each primer and $2 \mu \mathrm{L}$ of genomic DNA using the lyophilized AccuPower PCR Premix (Bioneer). Thermal conditions consisted of an initial incubation at $94^{\circ} \mathrm{C}$ for $2 \mathrm{~min}, 30$ cycles of $15 \mathrm{~s}$ at $94^{\circ} \mathrm{C}, 30 \mathrm{~s}$ at $57^{\circ} \mathrm{C}$, and $90 \mathrm{~s}$ at $72^{\circ} \mathrm{C}$, with a final extension at $72^{\circ} \mathrm{C}$ for $3 \mathrm{~min}$ (Byers et al., 2002). Genomic DNA from typical A. salmonicida (FPC 367 strain, Japan) was used as a positive control.

All vapA genes from the $A$. salmonicida isolates were amplified using the complete $A$. salmonicida vap $A$ gene-specific primers F-1 (5'-TCA ACG GAT AGG TTC AAC CC-3') and R-1 (5'-CAG AGT GAA ATC TAC CAG CGG TGC-3') as previously described to analyze the genetic diversity in typical A. salmonicida-specific vapA genes (Lund et al., 2003). After conducting 1\% agarose gel electrophoresis, the PCR products were purified using the AccuPrep gel purification kit (Bioneer) according to the manufacturer's protocol, and the DNA nucleotide sequence was analyzed using the ABI PRISM 3130xl Genetic Analyzer (Applied Biosystems, Foster City, CA, USA) available at National Instrumentation Center for Environmental Management, Seoul National University (NICEM, Seoul, Korea).

\section{Phylogenetic analysis}

DNA nucleotide sequences of all vapA genes were analyzed by multiple-sequence alignment using ClustalW2 (Thompson et al., 1994). Phylogenetic trees were generated using the Molecular Evolutionary Genetic Analysis software (MEGA) version 4 and the neighbor-joining method with bootstrap values of 1000 replicates (Tamura et al., 2007).

\section{Results}

\section{High prevalence of typical $A$. salmonicida isolates among chum salmon in Korea}

To examine the prevalence of typical A. salmonicida infection among chum salmon in Korea, 880 chum salmon samples, including wild adults $(n=560)$ and artificially hatched fry pools $(n=320)$ (Table 1$)$, were randomly collected and analyzed by the previously established PCR method using

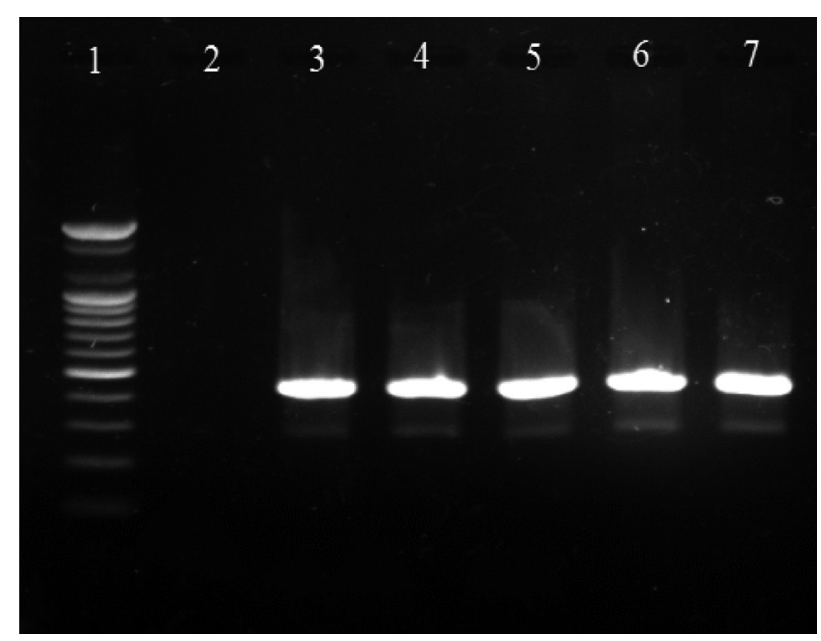

Fig. 1. Agarose gel electrophoresis of the $P C R$ products using the typical Aeromonas salmonicida-specific vapA gene primers AP1 and AP2. Lanes 1, 100-bp DNA marker; 2, negative control (no template DNA); 3, positive control (FPC367); 4, sample 1; 5, sample 2; 6, sample 3; 7, sample 4.

the vapA gene primers specific to typical A. salmonicida. The results demonstrated that approximately $34.5 \%$ of the samples (304/880 samples) produced the 421-bp amplicons specific to the vapA gene as expected (Fig. 1), implying that chum salmon infection by typical $A$. salmonicida is common in Korea (Table 1). Interestingly, the prevalence of typical A. salmonicida in the chum salmon fry pools was relatively higher in $2007(95.0 \%)$ and $2008(100 \%)$ than that in 2009 (28.6\%), $2010(3.0 \%)$, and $2011(0.0 \%)$ (Table 1). A similar pattern was observed in the adult chum salmon samples. The prevalence of $A$. salmonicida in the wild adult chum salmon was approximately $46.7,43.6$, and $42.5 \%$ in 2006,2007 , and 2008 , respectively, but decreased by $20.8 \%$ in 2009 and $12.5 \%$ in 2010 (Table 1).

\section{Isolation of typical $A$. salmonicida from the chum salmon samples and biochemical characteristics of isolates}

Twenty typical A. salmonicida isolates were recovered from the 304 wild adult chum salmon samples that were positive on the PCR using vapA-specific primers. As expected, all isolates were brown-pigmented when grown on TSA or FA plates, which is a characteristic of typical A. salmonicida. A preliminary screening confirmed that all 20 brown-pigmented isolates belonged to A salmonicida because all were Gramnegative, oxidase- and catalase-positive, non-motile rods and possessed the ability to reduce nitrate and degrade gelatin (data not shown).

The four typical $A$. salmonicida isolates were randomly selected, designated AsCh06, AsCh07, AsCh08, and AsCh09, respectively, and further characterized by biochemical tests 
(Table 2). The results showed that the AsCh08 and AsCh09 strains had the same biochemical phenotypes (API interpretation profile no. 0007124). However, they slightly differed from AsCh06 (API interpretation profile no. 0007024) and AsCh07 (API interpretation profile no. 2107124) in their biochemical activity, particularly for arginine dihydrolase, ornithine decarboxylase, mannitol fermentation, and sucrose fermentation (Table 2). The AsCh08 and AsCh09 strains were consistently able to produce all-blue colonies when cultured on CBBA plates due to surface A-layer protein expression. The antibiotic susceptibility test revealed that all typical $A$. salmonicida isolates were susceptible to various antibiotics including tetracyclines, aminoglycosides, $\beta$-lactam, and macrolides antibiotics but were resistant to nalidixic acid (data not shown).

\section{Phylogenetic analysis of the typical A. salmonici- da chum salmon isolates in Korea based on vapA gene diversity}

All vapA genes were amplified from the genomic DNA of AsCh06-09 by PCR and analyzed by DNA nucleotide sequencing for the phylogenetic analysis. The DNA sequence data were deposited in the GenBank database with the accession number GU734698. The analysis showed that all isolates carried identical vapA genes (data not shown). Based on the vapA gene sequences, a phylogenetic tree was produced by comparing the AsCh08 isolate with the typical A. salmonicida isolates from other countries (Table 3). Interestingly, AsCh08 showed $99.9 \%$ similarity and co-clustered with typical $A$. salmonicida strains previously isolated from Atlantic salmon and salmonids in Scotland and Norway such as A. salmonicida subsp. salmonicida 4012 (AJ749882), 4017 (AJ749881), A449 (CP000644), and A450 (M64655) strains (Table 4, Fig. 2). Although further detailed study is needed, it should be noted that AsCh08 showed less similarity ( $\sim 97 \%$ similarity) with other typical A. salmonicida isolates from Korea such as KCCM40239 (AB514572), RFAS1 (AB514573), and RFAS2 (AB514574) than with those from Atlantic salmon and salmonids in Scotland and Norway (Table 4, Fig. 2).

Table 2. Biochemical characteristics of the 4 vapA-positive and A-layer expressing typical Aeromonas salmonicida isolates from chum salmon in Korea

\begin{tabular}{|c|c|c|c|c|}
\hline \multirow{2}{*}{ Biochemical characteristics } & \multicolumn{4}{|c|}{ A. salmonicida isolates } \\
\hline & AsCh06 & AsCh 07 & AsCh08 & AsCh09 \\
\hline Gram stain & $\mathrm{G}(-)$ & $\mathrm{G}(-)$ & G(-) & $\mathrm{G}(-)$ \\
\hline Morphology & Rod & Rod & Rod & Rod \\
\hline Motility & - & - & - & - \\
\hline Brown pigment production & + & + & + & + \\
\hline Catalase & + & + & + & + \\
\hline Oxidase & + & + & + & + \\
\hline Oxidation-Fermentation & $\mathrm{F}$ & $\mathrm{F}$ & $\mathrm{F}$ & $\mathrm{F}$ \\
\hline Nitrate reduction & + & + & + & + \\
\hline b-galactosidase (ONPG) & - & - & - & - \\
\hline Arginine dihydrolase (ADH) & - & + & - & - \\
\hline Lysine decarboxylase (LDC) & - & - & - & - \\
\hline Ornithine decarboxylase (ODC) & - & + & - & - \\
\hline Urease (URE) & - & - & - & - \\
\hline Tryptophane deaminase (TDA) & - & - & - & - \\
\hline Indol production (IND) & - & - & - & - \\
\hline Voges-Proskauer reaction (VP) & + & + & + & + \\
\hline $\mathrm{H}_{2} \mathrm{~S}$ production & - & - & - & - \\
\hline Gelatine degradation (GEL) & + & + & + & + \\
\hline Citrate utilization (CIT) & - & - & - & - \\
\hline Glucose fermentation/oxidation (GLU) & + & + & + & + \\
\hline Mannitol fermentation/oxidation (MAN) & - & + & + & + \\
\hline Inositol fermentation/oxidation (INO) & - & - & - & - \\
\hline Sorbitol fermentation/oxidation (SOR) & - & - & - & - \\
\hline Rhamnose fermentation/oxidation (RHA) & - & - & - & - \\
\hline Sucrose fermentation/oxidation (SAC) & + & - & + & + \\
\hline Melibiose fermentation/oxidation (MEL) & - & - & - & - \\
\hline Amygdalin fermentation/oxidation (AMY) & - & - & - & - \\
\hline Arabinose fermentation/oxidation (ARA) & - & - & - & - \\
\hline Aesculin & - & - & - & - \\
\hline
\end{tabular}


Table 3. Aeromonas salmonicida strains used for phylogenetic analysis in this study

\begin{tabular}{|c|c|c|c|c|}
\hline A.salmonicida subspecies & Strain no. & GenBank Accession no. & Host & Country of origin \\
\hline salmonicida & 4128 & AJ749890 & $\begin{array}{l}\text { Spotted wolfish } \\
\text { Anarhichas minor }\end{array}$ & Norway \\
\hline salmonicida & 4099 & AJ749891 & $\begin{array}{l}\text { Atlantic cod } \\
\text { Gadus morhua }\end{array}$ & Norway \\
\hline salmonicida & 4137 & AM937253 & $\begin{array}{l}\text { Spotted wolfish } \\
\text { Anarhichas minor }\end{array}$ & Norway \\
\hline salmonicida & aAs4088 & AM937254 & $\begin{array}{l}\text { Spotted wolfish } \\
\text { Anarhichas minor }\end{array}$ & Norway \\
\hline salmonicida & 4129 & AJ749887 & $\begin{array}{l}\text { Spotted wolfish } \\
\text { Anarhichas minor }\end{array}$ & Norway \\
\hline salmonicida & 4059 & AM937252 & $\begin{array}{l}\text { Spotted wolfish } \\
\text { Anarhichas minor }\end{array}$ & Norway \\
\hline salmonicida & 4067 & AJ749885 & $\begin{array}{l}\text { Spotted wolfish } \\
\text { Anarhichas minor }\end{array}$ & Norway \\
\hline salmonicida & 4065 & AJ749884 & $\begin{array}{l}\text { Spotted wolfish } \\
\text { Anarhichas minor }\end{array}$ & Norway \\
\hline salmonicida & 4050 & AJ749892 & $\begin{array}{l}\text { Halibut } \\
\text { Hippoglossus hippoglossus }\end{array}$ & Norway \\
\hline salmonicida & RFAS1 & AB514573 & $\begin{array}{l}\text { Korean rockfish } \\
\text { Sebastes schlegeli }\end{array}$ & Korea \\
\hline salmonicida & RFAS2 & AB514572 & $\begin{array}{l}\text { Korean rockfish } \\
\text { Sebastes schlegeli }\end{array}$ & Korea \\
\hline salmonicida & KCCM402 & AB514574 & $\begin{array}{l}\text { Korean rockfish } \\
\text { Sebastes schlegeli }\end{array}$ & Korea \\
\hline salmonicida & 4012 & AJ749882 & $\begin{array}{l}\text { Atlantic salmon } \\
\text { Salmo salar }\end{array}$ & Scotland \\
\hline salmonicida & A449 & СР000644 & $\begin{array}{l}\text { Brown trout } \\
\text { Salmo trutta }\end{array}$ & France \\
\hline salmonicida & $\mathrm{A} 450$ & M64655 & Unknown & unknown \\
\hline salmonicida & 4017 & AJ749881 & $\begin{array}{l}\text { Atlantic salmon } \\
\text { Salmo salar }\end{array}$ & Norway \\
\hline salmonicida & 4122 & AJ749893 & $\begin{array}{l}\text { European flounder } \\
\text { Platichthys flesus }\end{array}$ & Finland \\
\hline This study & AsCh08 & GU734968 & $\begin{array}{l}\text { Chum salmon } \\
\text { Oncorhynchus keta }\end{array}$ & Korea \\
\hline achromogenes & 4036(АТCC33659) & AJ749888 & $\begin{array}{l}\text { Brook trout } \\
\text { Salmo trutta }\end{array}$ & UK \\
\hline achromogenes & 4111(NCBI1110) & AJ749889 & $\begin{array}{l}\text { Brook trout } \\
\text { Salmo trutta }\end{array}$ & UK \\
\hline achromogenes & aAs4101 & AM937255 & $\begin{array}{l}\text { Atlantic cod } \\
\text { Gadus morhua }\end{array}$ & Norway \\
\hline achromogenes & 4102 & AJ749886 & $\begin{array}{l}\text { Atlantic cod } \\
\text { Gadus morhua }\end{array}$ & Canada \\
\hline achromogenes & $117-92$ & AJ749879 & $\begin{array}{l}\text { Arctic Charr } \\
\text { Salvelinus alpinus }\end{array}$ & Finland \\
\hline masoucida & ATCC27013 & AJ749883 & $\begin{array}{l}\text { Masou salmon } \\
\text { Oncorhynchus masou }\end{array}$ & Japan \\
\hline smithia & NCIMB 13210 & AJ749880 & $\begin{array}{l}\text { Roach } \\
\text { Rutilus rutilus }\end{array}$ & UK \\
\hline
\end{tabular}




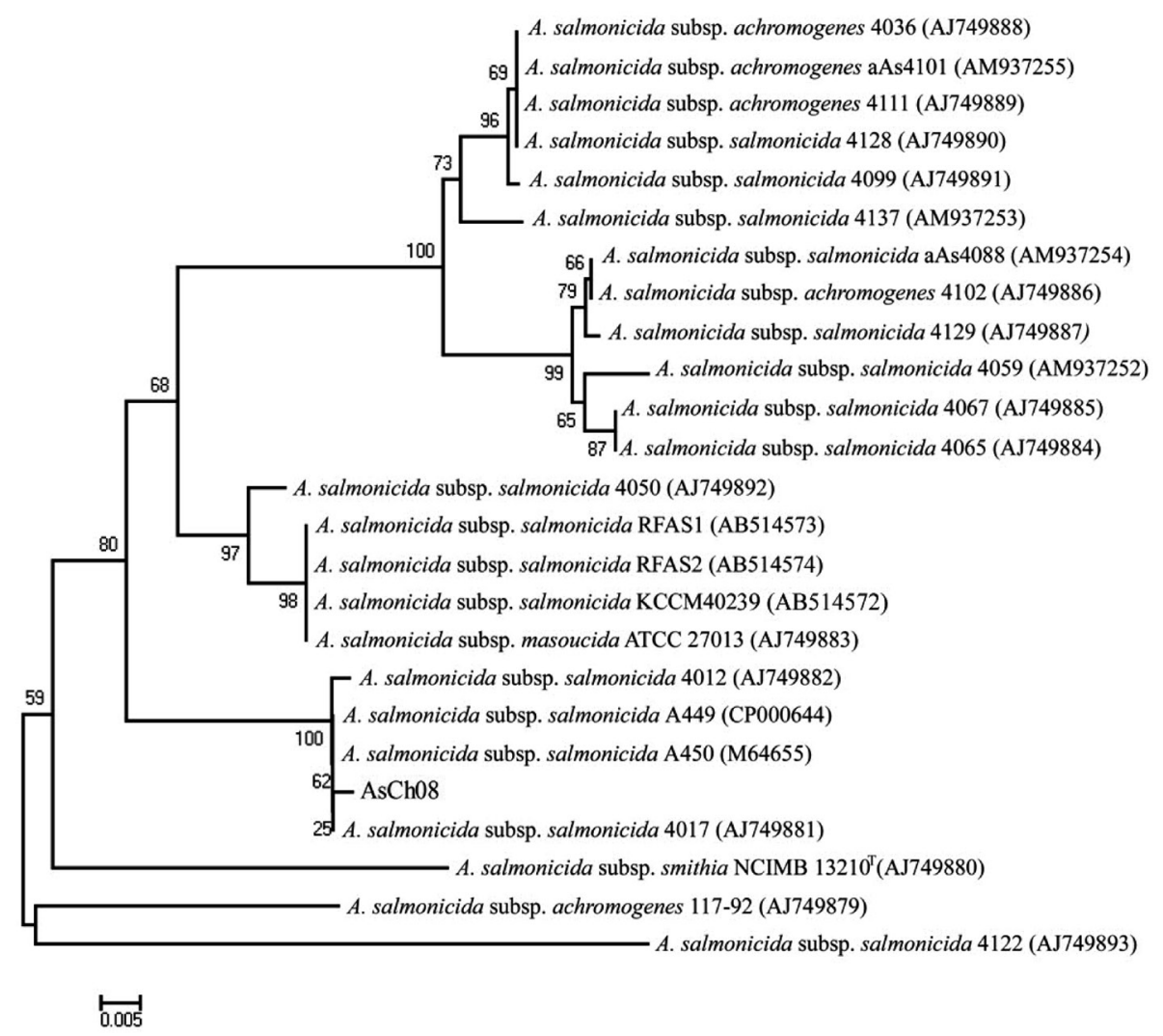

Fig. 2. Phylogenetic tree showing the genetic relationship of the chum salmon isolate (AsCh08) of typical Aeromonas salmonicida and the other A. salmonicida isolates based on the vapA gene sequences. The tree was constructed using neighbor-joining criteria with the bootstrap values at 1,000 replicates by MEGA4. Bar, 0.01 nucleotide substitution.

Table 4. Pairwise comparison of the vapA gene sequences among the typical Aeromonas salmonicida isolates worldwide and the chum salmon isolate of A. salmonicida (AsCh08) in this study

\begin{tabular}{|c|c|c|c|c|c|c|c|c|c|c|c|c|c|c|c|c|c|c|c|c|c|c|c|c|c|}
\hline \multirow{2}{*}{ No. } & \multirow{2}{*}{ Accession No. } & \multicolumn{24}{|c|}{ Nucleotide sequences identities (\%) } \\
\hline & & 1 & 2 & 3 & 4 & 5 & 6 & 7 & 8 & 9 & 10 & 11 & 12 & 13 & 14 & 15 & 16 & 17 & 18 & 19 & 20 & 21 & 22 & 23 & 24 \\
\hline 1 & AsCh08 & & & & & & & & & & & & & & & & & & & & & & & & \\
\hline 2 & СР000644 & 99.9 & & & & & & & & & & & & & & & & & & & & & & & \\
\hline 3 & AJ749881 & 99.9 & 0.0 & & & & & & & & & & & & & & & & & & & & & & \\
\hline 4 & AJ749882 & 99.8 & 99.9 & 99.9 & & & & & & & & & & & & & & & & & & & & & \\
\hline 5 & AJ749892 & 97.4 & 97.4 & 97.4 & 97.3 & & & & & & & & & & & & & & & & & & & & \\
\hline 6 & M64655 & 99.7 & 99.9 & 99.9 & 99.8 & 97.2 & & & & & & & & & & & & & & & & & & & \\
\hline 7 & AB514573 & 97.2 & 97.2 & 97.2 & 97.2 & 98.3 & 97.1 & & & & & & & & & & & & & & & & & & \\
\hline 8 & AB514574 & 97.4 & 97.4 & 97.4 & 97.3 & 98.5 & 97.2 & 99.9 & & & & & & & & & & & & & & & & & \\
\hline 9 & AB514572 & 97.2 & 97.2 & 97.2 & 97.2 & 98.5 & 97.1 & 99.7 & 99.9 & & & & & & & & & & & & & & & & \\
\hline 10 & AJ749883 & 97.2 & 97.2 & 97.2 & 97.2 & 98.5 & 97.1 & 99.7 & 99.9 & 0.0 & & & & & & & & & & & & & & & \\
\hline 11 & AJ749891 & 96.3 & 96.3 & 96.3 & 96.3 & 96.9 & 96.2 & 96.6 & 96.8 & 96.8 & 96.8 & & & & & & & & & & & & & & \\
\hline 12 & AJ749890 & 96.3 & 96.3 & 96.3 & 96.2 & 96.9 & 96.1 & 96.7 & 96.9 & 96.9 & 96.9 & 99.9 & & & & & & & & & & & & & \\
\hline 13 & AJ749889 & 96.3 & 96.3 & 96.3 & 96.2 & 96.9 & 96.1 & 96.7 & 96.9 & 96.9 & 96.9 & 99.9 & 0.0 & & & & & & & & & & & & \\
\hline 14 & AM937254 & 95.5 & 95.5 & 95.5 & 95.4 & 96.4 & 95.3 & 96.1 & 96.3 & 96.3 & 96.3 & 98.5 & 98.5 & 98.5 & & & & & & & & & & & \\
\hline 15 & AJ749886 & 95.5 & 95.5 & 95.5 & 95.4 & 96.4 & 95.3 & 96.1 & 96.3 & 96.3 & 96.3 & 98.5 & 98.5 & 98.5 & 0.0 & & & & & & & & & & \\
\hline 16 & AJ749887 & 95.4 & 95.4 & 95.4 & 95.3 & 96.4 & 95.3 & 96.1 & 96.2 & 96.2 & 96.2 & 98.3 & 98.4 & 98.4 & 99.9 & 99.9 & & & & & & & & & \\
\hline 17 & AJ749885 & 95.3 & 95.3 & 95.3 & 95.3 & 96.3 & 95.2 & 96.0 & 96.1 & 96.1 & 96.1 & 98.1 & 98.2 & 98.2 & 99.6 & 99.6 & 99.5 & & & & & & & & \\
\hline 18 & AJ749884 & 95.3 & 95.3 & 95.3 & 95.3 & 96.3 & 95.2 & 96.0 & 96.1 & 96.1 & 96.1 & 98.3 & 98.3 & 98.3 & 99.8 & 99.8 & 99.6 & 99.9 & & & & & & & \\
\hline 19 & AJ749879 & 95.3 & 95.3 & 95.3 & 95.4 & 95.0 & 95.2 & 94.9 & 95.0 & 94.9 & 94.9 & 94.4 & 94.3 & 94.3 & 94.3 & 94.3 & 94.2 & 94.1 & 94.1 & & & & & & \\
\hline 20 & AJ749888 & 93.4 & 93.4 & 93.4 & 93.4 & 94.1 & 93.3 & 93.9 & 94.0 & 94.0 & 94.0 & 97.1 & 97.1 & 97.1 & 95.7 & 95.7 & 95.6 & 95.3 & 95.5 & 91.5 & & & & & \\
\hline 21 & AJ749880 & 94.7 & 94.8 & 94.8 & 94.7 & 94.8 & 94.6 & 94.3 & 94.4 & 94.3 & 94.3 & 94.1 & 94.0 & 94.0 & 93.8 & 93.8 & 93.7 & 93.7 & 93.7 & 95.3 & 91.2 & & & & \\
\hline 22 & AJ749893 & 92.4 & 92.5 & 92.5 & 92.5 & 92.6 & 92.4 & 92.3 & 92.4 & 92.4 & 92.4 & 92.4 & 92.4 & 92.4 & 92.0 & 92.0 & 91.9 & 91.9 & 91.9 & 93.1 & 89.5 & 92.3 & & & \\
\hline 23 & AM937255 & 31.3 & 31.3 & 31.3 & 31.3 & 32.0 & 31.3 & 31.8 & 31.8 & 31.8 & 31.8 & 34.0 & 34.0 & 34.0 & 33.2 & 33.2 & 33.1 & 32.9 & 32.9 & 30.1 & 34.9 & 30.4 & 29.5 & & \\
\hline 24 & AM937253 & 31.1 & 31.1 & 31.1 & 31.0 & 32.1 & 31.1 & 31.8 & 31.8 & 31.9 & 31.9 & 33.3 & 33.4 & 33.4 & 33.0 & 33.0 & 32.9 & 32.8 & 32.8 & 30.1 & 34.3 & 30.1 & 29.5 & 98.1 & \\
\hline 25 & AM937252 & 29.0 & 29.0 & 29.0 & 28.9 & 29.6 & 29.0 & 29.4 & 29.4 & 29.5 & 29.5 & 30.8 & 30.7 & 30.7 & 31.8 & 31.8 & 31.7 & 32.0 & 32.0 & 28.2 & 31.5 & 28.4 & 27.5 & 89.4 & 89.4 \\
\hline
\end{tabular}




\section{Discussion}

Wild adult chum salmon samples positive for the $A$. salmonicida vapA gene were used for bacterial isolation, and the colonies producing a diffusible brown pigment, a characteristic of typical A. salmonicida isolates, were further examined. Biochemical analyses revealed that all brown-pigmented isolates were Gram-negative, oxidase-positive, catalase-positive, non-motile rods. They also produced dark blue colonies when cultured on CBBA plates, suggesting the presence of an A-layer (Cipriano and Bertolini, 1988). These results are consistent with the biochemical characteristics of typical $A$. salmonicida (Pavan et al., 2000). The PCR results showed that typical $A$. salmonicida was consistently detected at a high prevalence in both wild adult chum salmon and artificially hatched fry pools during 2006-2011. A similar long-term study reported a 1.7-50\% prevalence of typical $A$. salmonicida infection in adult chum salmon from Japanese rivers (Nomura et al., 2002). Several other studies also showed that furunculosis is enzootic among wild salmon populations in rivers (Austin and Austin, 2007 and the references therein).

Typical A. salmonicida strains are thought to be extremely homogeneous. Therefore, epidemiological discrimination among the strains based on either phenotypic or biochemical properties has shown limited success in elucidating their geographical relatedness and/or host preference. Moreover, conventional genotypic methods such as plasmid profiling and ribotyping of $A$. salmonicida do not provide a clear epidemiological marker for furunculosis outbreaks (Nielsen et al., 1993, 1994). Sequencing of the 16rRNA gene is a robust tool for bacterial taxonomy, but genetic analysis of the 16S rRNA gene revealed that it is highly conserved in the genus Aeromonas (Martínez-Murcia et al., 2005). The vapA gene sequences of the five typical $A$. salmonici$d a$ isolates have been investigated, and results showed that they were identical and were grouped into the same cluster (Lund and Mikkelsen, 2004). Nonetheless, typical $A$. salmonicida strains were resolved in two clusters by geographical origin; one cluster contains mainly North American strains, and the other cluster contains mainly northern European strains (O'hlci et al., 2000). In the present study, the AsCh08 vapA gene sequence (GenBank accession no. GU734968) showed $99.9 \%$ similarity with that of A. salmonicida subsp. salmonicida strains A449 (GenBank accession number CP000644) and 4017 (GenBank accession no. AJ749881). In this study, AsCh08 was clustered with typical $A$. salmonicida type strain A450 (GenBank accession no. M64655) and type strains 4012 (GenBank accession no. AJ749882), 4017 (GenBank accession no. AJ749881), and A449 (GenBank accession no. CP000644). Unexpectedly, these strains were isolated from Atlantic salmon and salmonids in Scotland and Norway, all of which are geographically distant from Korea. Although this phenomenon cannot be explained, it would be interesting to investigate the possible relationship between these isolates and their geographical origin in detail.

A phylogenetic tree of 23 typical and atypical A. salmonicida strains has been reported based on their vapA gene sequences (Lund and Mikkelsen, 2004). The results demonstrated that most of the vapA gene sequence is highly conserved and that all typical $A$. salmonicida strains are localized in the same phylogenic cluster regardless of their geographic origin. Therefore, more discriminative genetic markers are required for epidemiological studies because it is still uncertain how this pathogen has been disseminated worldwide and how it affects wild salmonid populations.

In conclusion, typical $A$. salmonicida infection among chum salmon in Korea was monitored by PCR during 2006-2011, and the infection demonstrated a high prevalence. Although no information is currently available on the pathogenic potential of these pathogens and to what extent they have affected propagation of chum salmon in Korea, an appropriate control method should be considered to prevent possible clinical outbreaks in holding ponds and/or hatcheries. Affected wild adult chum salmon with typical A. salmonicida could act as carriers by transporting the pathogen to spawning areas (Nomura et al., 2002).

\section{Acknowledgments}

This research was partly supported by the Marine and Extreme Genome Research Center Program of the Ministry of Land, Transportation and Maritime Affairs, Republic of Korea. The authors thank Dr. Shotaro Izumi from Gunma Prefecture Fisheries Experimental Station, Japan, for providing typical A. salmonicida DNA as a positive control, and also thank all the staffs in Yangyang Salmon Station, Korea Fisheries Resources Agency for their help in collecting fish samples.

\section{References}

Abbott SL, Cheung WK and Janda JM. 2003. The genus Aeromonas: biochemical characteristics, atypical reactions, and phenotypic identification schemes. J Clin Microbiol 41, 2348-2357.

Austin B and Austin D. 2007. Bacterial Fish Pathogens: Diseases of Farmed and Wild Fish. 4th ed. Springer-Praxis, Chichester, GB, pp. 25-89.

Byers HK, Gudkovs N and Crane MS. 2002. PCR-based assays for the fish pathogen Aeromonas salmonicida. I. Evaluation of three PCR primer sets for detection and identification. Dis Aquat Org 49, 129138.

Cipriano RC and Bertolini J. 1988. Selection for virulence in the fish pathogen Aeromonas salmonicida, using Coomassie Brilliant Blue agar. J Wildl Dis 24, 672-678.

Fryer JL, Hedrick RP, Park JW and Hah YC. 1988. Isolation of Aeromonas salmonicida from masu salmon in the Republic of Korea. $\mathrm{J}$ Wildl Dis 24, 364-365.

Gustafson CE, Thomas CJ and Trust TJ. 1992. Detection of Aeromonas salmonicida from fish by using polymerase chain reaction amplification of the virulence surface array protein gene. Appl Environ 
Microbiol 58, 3816-3825.

Johnsen BO and Jensen AJ. 1994. The spread of furunculosis in salmonids in Norwegian rivers. J Fish Biol 45, 47-55.

Lee C, Cho JC, Lee SH, Lee DG and Kim SJ. 2002. Distribution of Aeromonas spp. as identified by $16 \mathrm{~S}$ rDNA restriction fragment length polymorphism analysis in a trout farm. J Appl Microbiol 93, 976-985.

Lund V, Espelid S and Mikkelsen H. 2003. Vaccine efficacy in spotted wolffish Anarhichas minor: relationship to molecular variation in A-layer protein of atypical Aeromonas salmonicida. Dis Aquat Org $56,31-42$.

Lund V and Mikkelsen H. 2004. Genetic diversity among A-proteins of atypical strains of Aeromonas salmonicida. Dis Aquat Org 61, 257-262.

Martínez-Murcia AJ, Soler L, Saavedra MJ, Chacón MR, Guarro J, Stackebrandt E and Figueras MJ. 2005. Phenotypic, genotypic, and phylogenetic discrepancies to differentiate Aeromonas salmonici$d a$ from Aeromonas bestiarum. Int Microbiol 8, 259-269.

Mooney J, Powell E, Clabby C and Powell R. 1995. Detection of Aeromonas salmonicida in wild Atlantic salmon using a specific DNA probe test. Dis Aquat Org 21, 131-135.

National Committee for Clinical Laboratory Standard. 2001. Clinical Laboratory Standard of Antimicrobial Susceptibility (NCCLS) (2001) Testing: Eleventh Information Supplement. National Committee for Clinical Laboratory Standard of Antimicrobial Susceptibility, Wayne, PA, US.

Nielsen B, Olsen JE and Larsen JL. 1993. Plasmid profiling as an epidemiological marker within Aeromonas salmonicida. Dis Aquat
Org 15, 129-135.

Nielsen B, Olsen JE and Larsen JL. 1994. Ribotyping of Aeromonas salmonicida subsp. salmonicida. Dis Aquat Org 18, 155-158.

Nomura T, Honma H, Kasai H and Yoshimizu M. 2002. Isolation of Aeromonas salmonicida, causative agent of furunculosis, from chum salmon caught in the river or coast. Bull Fish Sci Hokkaido Univ 53, 45-50.

O'hlci B, Olivier G and Powell R. 2000. Genetic diversity of the fish pathogen Aeromonas salmonicida demonstrated by random amplified polymorphic DNA and pulsed-field gel electrophoresis analyses. Dis Aquat Org 39, 109-119.

Pavan ME, Abbott SL, Zorzópulos J and Janda JM. 2000. Aeromonas salmonicida subsp. pectinolytica subsp. nov., a new pectinase-positive subspecies isolated from a heavily polluted river. Int J Syst Evol Miccrobiol 50(Pt 3), 1119-1124.

Tamura K, Dudley J, Nei M and Kumar S. 2007. MEGA4: Molecular Evolutionary Genetics Analysis (MEGA) software version 4.0. Mol Biol Evol 4, 1596-1599.

Thompson JD, Higgins DG and Gibson TJ. 1994. CLUSTAL W: improving the sensitivity of progressive multiple sequence alignment through sequence weighting, position-specific gap penalties and weight matrix choice. Nucleic Acids Res 22, 4673-4680.

Trust TJ, Khouri AG, Austen RA and Ashburner LD. 1980. First isolation in Australia of atypical Aeromonas salmonicida. FEMS Microbiol Lett 9, 39-42.

Wiklund T and Dalsgaard I. 1998. Occurrence and significance of atypical Aeromonas salmonicida in non-salmonid and salmonid fish species: a review. Dis Aquat Org 32, 49-69. 